\title{
PENELITIAN TINDAKAN KELAS DALAM KONTEKS PEMBELAJARAN BAHASA JERMAN
}

\author{
Aditya Rikfanto ${ }^{1}$, Sridanto Farras Rachmadi ${ }^{2}$ \\ ${ }^{1}$ Universitas Negeri Yogyakarta, Indonesia \\ ${ }^{2}$ Hochschule für Technik und Wirtschaft Berlin, Jerman \\ e-mail: adityarikfanto@uny.ac.id
}

\begin{abstract}
(Title: Class Action Research in the Context of German Language Learning). As a means of problem-solving, research methods continue to evolve. In the ' 40 s began to be known action research, and this research was also applied in the classroom or called Class Action Research (CAR). This type of research is becoming increasingly popular to evaluate the learning process of German Language Teaching. However, the focus of CAR talks in German language learning is still likely to be rare. This paper discusses the characteristics and application of CAR in German language learning. In addition, this article also reviews the situation of German learning in general. Thus the article can contribute scientifically to teachers and educators in improving performance in their fields.
\end{abstract}

Keywords: Action Research, CAR, Learning, German Language

\section{PENDAHULUAN}

Praktik pendidikan berkembang secara progresif dan terus beriringan dengan perkembangan ilmu pengetahuan. Di sisi lain, permasalahan dalam pendidikan juga datang silih berganti, baik pada tataran teknis pelaksanaan maupun pemerataan mutu. Jika persoalan demi persoalan tidak diselesaikan, maka hal ini menyebabkan kualitas pendidikan semakin jauh dari harapan. Fenomena tersebut tentu menjadi kesenjangan antara idealita (das Sollen) dengan kenyataan (das Sein). Berbagai permasalahan yang kemudian muncul dalam dunia pendidikan, tentu menuntut jawaban dan solusi berkelanjutan.

Guru dan calon guru sebagai komponen pendidikan terpenting dituntut untuk membekali diri dengan kompetensi dan kualifikasi akademis yang mapan. Dalam menjalankan tugas dan fungsinya, guru harus mampu mem- berikan solusi terhadap permasalahan yang muncul dalam proses pendidikan. Salah satu kompetensi yang harus dimiliki adalah kemampuan melaksanakan penelitian. Kemampuan meneliti merupakan hasil dari kumpulan pengalaman interaksi antara guru dengan bidang kerja, ditambah dengan penguasaan teori dari berbagai referensi ilmiah. Dengan demikian, guru mampu melahirkan gagasan dan tindakan baru yang substansial serta dapat memecahkan kebuntuan pada proses pendidikan.

Hari ini, jenis penelitian yang populer diterapkan pada bidang pendidikan adalah penelitian tindakan kelas (PTK). Hal tersebut dapat dimengerti, sebab PTK diyakini dapat menjadi sarana untuk menyelesaikan kesenjangan antara harapan dan kenyataan. PTK sangat populer di kalangan praktisi pendidikan, sebab selain tuntutan karir, mereka juga dituntut secara esensial untuk mampu menghasilkan perubah- 
an, pembaharuan, evaluasi dan refleksi dalam kegiatan kelasnya (Meesuk et al., 2020).

Memang pembahasan tentang PTK telah banyak dan mudah ditemukan, baik pada jurnal ilmiah maupun dalam buku-buku metodologi penelitian. Akan tetapi fokus bahasan PTK dalam konteks pembelajaran Bahasa Jerman masih cenderung jarang. Oleh karena itu, artikel ini mencoba memberikan kontribusi dalam menjelaskan karakteristik dan penerapan PTK dalam pembelajaran Bahasa Jerman.

\section{SITUASI PEMBELAJARAN BAHASA JERMAN}

Sebelum membahas lebih lanjut tentang penelitian tindakan kelas, bagian ini akan mengulas situasi dan perkembangan pembelajaran Bahasa Jerman secara umum, dalam rangka menempatkan konteks penerapan PTK secara tepat.

Sebagai bahasa asing yang cukup berpengaruh di daratan Eropa, Bahasa Jerman menjadi pelajaran yang sangat diminati di kalangan pelajar Indonesia. Sejak 2005, jumlah pembelajar Bahasa Jerman di dunia telah mencapai 14,5 Juta dan 40.000 orang di antaranya adalah pembelajar Indonesia (Auswärtiges Amt, 2015). Jumlah ini semakin melonjak, dimana pembelajar Indonesia di tingkat sekolah menengah telah meningkat hampir tiga kali lipat pada tahun 2020, yaitu sekitar 150.000 orang, dengan kisaran guru 1.500 orang (Auswärtiges Amt, 2020). Jumlah yang besar ini tentu menjadi peluang serta tantangan tersendiri dalam bidang pembelajaran Bahasa Jerman. Tenaga pendidik harus mampu mencetak generasi pembelajar yang terampil, baik untuk mendukung keperluan akademis maupun membuka masa depan bagi karirnya. Oleh karena itu, proses pembelajaran harus dikembangkan sebaik mungkin, sehingga dapat memiliki karakter dan memberikan substansi yang holistik, integratif, interaktif, kontekstual, relevan, efisien dan efektif (Pitoyo, 2020).

Tujuan pembelajaran Bahasa Jerman di sekolah menengah tingkat atas adalah mencetak peserta didik yang memiliki kemampuan dasar dalam keterampilan mendengarkan, berbicara, membaca, menulis untuk berkomunikasi secara sederhana. Dengan kata lain, keterampilan berbahasa Jerman seharusnya dapat diwujudkan dalam bentuk komunikasi secara memadai, baik lisan maupun tertulis (Santoso, 2016).

Oleh sebab itu, sudah selayaknya fokus pembelajaran Bahasa Jerman diarahkan pada pengembangan empat keterampilan pokok, ditambah dengan penguasaan gramatika serta kosakata yang mendasari keempat keterampilan pokok tersebut.

\section{Keterampilan Membaca}

Apryliana (2020) berpendapat, bahwa membaca bukan hanya kegiatan untuk mendapatkan informasi semata, melainkan sebuah proses kompleks yang melibatkan seluruh aktivitas mental dan kemampuan berpikir peserta didik dalam memahami, mengkritisi, dan bahkan memproduksi kembali dalam sebuah wacana tulis.

Sebagai bentuk kemampuan komunikasi reseptif, membaca merupakan bagian tidak terpisahkan dalam pembelajaran Bahasa Jerman. Westhoff, (1997) menyatakan, bahwa kemampuan membaca meliputi beberapa kategori: 1) Membaca detail untuk mengetahui obyek secara teliti dan total (detailliertes/ totales Lesen); 2) Membaca selektif untuk menemukan informasi spesifik (selektives/ suchendes Lesen); dan 3) Membaca global untuk mendapatkan kesan secara umum (globales/ kursorisches Lesen).

Meskipun terkesan mudah, namun sebenarnya tipikal bacaan Bahasa Jerman merupakan bidang yang kompleks. Adamczak-Krysz- 
tofowicz \& Stolarczyk (2014) menyatakan dalam sebuah studi terhadap 13 pelajar di kota Darmstadt dan kota Poznań, bahwa sedikit pembelajar yang mampu mencatat keberhasilan belajar di bidang membaca wacana, yaitu $20 \%$. Fakta ini menjadi contoh kasus, bahwa pembelajaran membaca juga rentan menimbulkan berbagai persoalan di kalangan penutur asing Bahasa Jerman.

\section{Keterampilan Mendengar}

Kegiatan mendengar dalam pembelajaran Bahasa Jerman pada awalnya memang tidak dipandang sebagai hal yang strategis. Baru di era 70-an, para pendidik menyadari urgensinya dan menempatkan kegiatan mendengar sebagai bagian penting dalam pembelajaran bahasa asing.

Meskipun esensi keterampilan mendengarkan telah diakui saat ini, namun strategi pengembangan keterampilan mendengarkan masih belum diterapkan secara sistematis dalam banyak kasus. Bahkan pendekatan yang digunakan dalam penilaian mendengarkan masih cenderung berorientasi pada hasil, dibanding pendekatan berbasis proses (Niewalda et al., 2016).

Dahlhaus et al. (1994) menyatakan ada dua tipologi latihan pengembangan keterampilan mendengar. Pertama, penugasan verbal (verbale Aufgaben), artinya seperangkat latihan yang digunakan untuk mengasah kemampuan menyimak narasi eksplisit. Latihan ini ditandai dengan pertanyaan 6W: was, wer, wann, wie, warum, wo. Kedua, penugasan non verbal (nichtverbale Aufgaben), artinya seperangkat latihan digunakan untuk mengasah kemampuan menyimak narasi implisit, ditandai dengan prediksi tuturan yang selaras dengan situasi. Tujuan latihan ini adalah menciptakan pengertian dengan bantuan visual dan menemukan informasi yang tidak diucapkan.

\section{Keterampilan Berbicara}

Menurut Mead (2014), kemampuan berbicara dapat dilihat dari dua segi, pertama adalah kemampuan naratif yang digunakan untuk mengartikan kata-kata dan menyampaikan informasi kepada pendengar (conveying the story/ Informations). Kedua, kemampuan dialogis untuk menerima stimulus dan menyampaikan respon secara bergantian antar peserta didik (interchangeable communication).

Dalam pembelajaran Bahasa Jerman, tipologi latihan berbicara cukup beragam. Schatz et al. (2006) menyebutkan setidaknya ada empat jenis latihan berbicara, yaitu: 1) Latihan pelafalan (Aussprache und Intonation), yaitu latihan berbicara dasar, dimana peserta didik perlu mengembangkan keterampilan pengucapan huruf per huruf, kata per kata dan kalimat per kalimat. Hal ini mendapat perhatian utama dalam pembelajaran berbicara. Kenapa? Sebab kemampuan komunikasi Bahasa Jerman sangat ditentukan oleh cara pengucapan. Jika pengucapan peserta didik tepat, maka penerimaan atau pemahaman pendengar menjadi baik. Dengan sendirinya, tujuan komunikasi menjadi dapat tercapai. Sebaliknya jika pengucapan tidak tepat dan banyak menyimpang, maka keterpahaman bahasa menjadi terhambat, bahkan kekeliruan pengucapan jauh lebih buruk dibanding kesalahan yang diakibatkan oleh pilihan kata atau tata bahasa (Dahmen \& Hirschfeld, 2016); 2) Berbicara mandiri (monologische Redebeiträge), yaitu jenis latihan yang digunakan untuk memberitakan, menceritakan atau mendeskripsikan sesuatu secara sadar dan mandiri. 3) Berbicara dialogis (Dialogarbeit), yaitu jenis latihan untuk mengembangkan keterampilan dialogis dengan tema situasi keseharian; dan 4) Diskusi (Pro-Kontra-Diskussion), yaitu latihan berbicara dalam bentuk diskusi, dimana pendapat pro dan kontra diargumentasikan secara san- 
tun. Pada akhir pembicaraan, peserta didik diharapkan dapat bersepakat pada satu keputusan/ kesimpulan.

Kondisi pengembangan keterampilan berbicara tentu masih dilematis. Dalam sebuah studi Hoch et al., (2016) mengatakan, bahwa ada kontradiksi pada penerapan prinsip Bahasa Jerman sebagai target dalam penerapan di kelas. $92 \%$ pembelajar Bahasa Jerman menyatakan, bahwa mereka jarang berbicara Bahasa Jerman dalam jam pelajaran. Di sisi lain, $61 \%$ guru Bahasa Jerman berbicara Bahasa Jerman dalam waktu kurang dari seperempat dari waktu mengajar.

\section{Keterampilan Menulis}

Pembelajaran menulis pada hakikatnya merupakan upaya sadar untuk mengembangkan kreativitas diri pembelajar dalam menggunakan kalimat, mulai dari pembukaan sampai penyelesaian sebuah teks (Haryati, 2017). Penggunaan kosakata, tata bahasa dan struktur penulisan harus dimiliki oleh peserta didik dan dapat digunakan secara terampil dalam rangka menentukan fungsi dan tujuan tulisan (Apryliana, 2017).

Kast (1999) menyatakan, bahwa kemampuan menulis dapat dibangun dari beberapa latihan secara berjenjang dan terarah. Tipologi latihan yang dibangun dalam pelajaran Bahasa Jerman, secara umum meliputi empat jenis: 1) Latihan persiapan (vorbereitende Übungen), seperti pemantapan tata tulis, penulisan katakata kunci dan pembuatan jembatan ide; 2) Latihan pengembangan (aufbaunde Übungen), seperti pengembangan kata-kata menjadi kalimat, koneksi antar kalimat dan penulisan paragraf; 3) Latihan terstruktur (strukturierte Übung), seperti produksi teks secara terarah, melengkapi teks, penulisan dialog, deskripsi gambar menjadi cerita; dan 4) Latihan menulis secara terarah dan komunikatif berbasis situa- si keseharian (auf reale Kommunikationssituationen bezogenes Schreiben), seperti menulis dan membalas surat. Tipe-tipe latihan menulis yang cukup luas ini tentu rentan menimbulkan berbagai persoalan di kalangan pembelajar.

\section{Pembelajaran Gramatika}

Tata Bahasa Jerman sangat kompleks dan luas cakupannya. Untuk dapat memahami Bahasa Jerman, pembelahar perlu menguasai kaidah gramatika dengan baik. Pembelajaran Bahasa Jerman berbasis gramatika (Die Grammatik-Übersetzungsmethode/ $G \ddot{U} M)$ memang menjadi titik sentral utama dan mengakar kuat dalam praktik pendidikan sampai abad 19 . Akan tetapi metode ini telah menuai kritik di kalangan pakar. Rösler (2012) menyatakan, jika Bahasa Jerman diterapkan pada penutur asli yang mendalami studi linguistik dan teksteks budaya tinggi, maka gramatika menjadi hal yang menarik. Akan tetapi, jika tujuan pembelajaran adalah pengembangan kompetensi komunikatif bagi penutur asing, maka metode gramatika menjadi kurang tepat dan acap kali menimbulkan persoalan.

Dalam dekade saat ini, pembelajaran gramatika cenderung diintegrasikan dalam kemampuan komunikasi umum. Dengan demikian, grammatika dapat masuk pada empat keterampilan pokok secara fleksibel. Hunold (2009) menyatakan, bahwa pada awalnya pendekatan komunikatif sering ditolak oleh para pembelajar dan guru sendiri, sebab mereka sudah terbiasa dengan metode yang lebih konvensional (metode terjemah gramatika). Akan tetapi seiring perubahan global, pembelajar semakin kritis untuk menemukan bentuk pembelajaran yang lebih komunikatif. Pada akhirnya, penerimaan metode komunikatif menjadi semakin tinggi. Metode ini terbukti menghasilkan output penutur bahasa asing yang lebih luwes dan cepat beradaptasi di berbagai situasi. 
Berbagai keterampilan dasar kebahasaan di atas tentu menyimpan berbagai potensi permasalahan, baik dalam praktik pengajaran maupun pada penerapannya oleh perserta didik. Oleh karena itu, metode penelitian PTK hadir menjadi sarana pemecahan masalah secara tepat.

\section{PENELITIAN TINDAKAN KELAS: TEORI DAN PENERAPAN}

Penelitian tindakan semakin berkembang di dunia pendidikan sejak era 70-an. Di saat Amerika mulai meninggalkan metode penelitian tindakan, Inggris justru mulai mendalami dan mengembangkan metode ini, secara khusus untuk pengembangan pengajaran (McNiff $\&$ Whitehead, 2006). Metode penelitian ini semakin dikenal dan digunakan secara luas di dunia. Sedangkan di Indonesia, tren proyek penelitian berbasis PTK semakin menonjol sejak dua dekade terakhir.

Penelitian Tindakan Kelas (PTK) adalah jenis penelitian berbasis tindakan yang dilaksanakan di dalam kelas, saat pembelajaran sedang berlangsung. PTK dilakukan dengan tujuan untuk memperbaiki atau meningkatkan kualitas pembelajaran, dimana fokus utama penelitian adalah peningkatan proses pembelajaran di dalam kelas (Wijaya et al., 2013). Rustam \& Mundilarto (2004) menyatakan, bahwa penelitian tindakan kelas adalah sebuah penelitian yang dilakukan oleh guru di kelasnya sendiri dengan jalan merancang, melaksanakan dan merefleksikan tindakan secara kolaboratif dan partisipatif. Tujuan tindakan tersebut adalah untuk memperbaiki kinerja guru sekaligus meningkatkan mutu belajar siswa.

Widayati (2008) berpendapat, bahwa PTK menjadi tantangan bagi para guru dalam rangka meningkatkan profesionalitas sebagai tenaga pendidik. Hal ini berdasarkan pada tiga alasan: Pertama, guru menjadi semakin pe- ka, mawas dan tanggap terhadap dinamika pembelajaran di kelasnya, baik selama pelaksanaan penelitian maupun dalam kegiatan pembelajaran seterusnya. Kedua, PTK mampu meningkatkan performa guru, dimana mereka tidak lagi berpandangan sempit dan merasa puas pada capaian kinerja selama bertahun-tahun. Sebaliknya, mereka terus melakukan perbaikan dan inovasi. Ketiga, guru mampu memperbaiki proses pembelajaran di kelas berbasis kajian kritis dan penilaian ilmiah terhadap apa yang terjadi di kelasnya.

Sebagai kegiatan ilmiah yang kaya, metode PTK dapat bermanfaat bagi sekolah, akademisi, dan masyarakat. Nolen \& Putten (2007) menyatakan, bahwa beberapa pakar memang mempersoalkan isu-isu kritis yang berkaitan dengan penelitian tindakan kelas, misalnya: Apakah penelitian ini akuntabel? Apakah guru terlatih dengan baik untuk melihat persoalan dan melaksanakan penelitian semacam itu? Apakah tersedia sumber-sumber yang memadai untuk menghimpun dan menganalisa temuan secara efektif? Pertanyaan ini masih menjadi diskusi panjang. Namun demikian, PTK tetap menjadi proyek berharga, jika dilakukan oleh praktisi pendidikan yang terampil, memiliki pengetahuan, kejelasan kerja, akses informasi dan kredibilitas di sekolah secara mapan.

\section{KARAKTERISTIK PENELITIAN TINDAKAN KELAS DALAM KONTEKS PEMBELAJARAN BAHASA JERMAN}

Jika kita berbicara tentang penerapan PTK dalam pembelajaran Bahasa Jerman, maka fokus tindakan diarahkan pada peningkatan proses pembelajaran (to improve aspects of teaching). Selain itu, PTK menyasar pada perbaikan kinerja guru dalam menyampaikan isi serta prosedur pembelajaran (to evaluate the success of certain activities and procedures) (Harmer, 2105). 
Sebagai penelitian yang berbasis pada bidang sosial, PTK memiliki beberapa karakteristik, yaitu: 1) Berbasis pada masalah yang ditemukan di kelas sebagai ruang sosial; 2) Bertujuan untuk mengembangkan kualitas dinamika dan proses pembelajaran; 3) Keterlibatan pihak-pihak yang inklusif, yaitu siswa, guru atau rekan sejawat di lingkungan pendidikan; 4) Sistematis, namun temuan PTK tidak dapat digeneralisir, sebab sampelnya sangat terbatas dan topiknya sangat situasional, 5) Tindakan dilakukan beberapa kali siklus atau putaran (cyclical), dimana siklus tindakan tersebut berfungsi untuk memvalidasi dan menyempurnakan tindakan penelitian (Norton, 2009). Siklus tindakan ini sangat khas, artinya tindakan pemecahan masalah dapat berwujud penguatan tindakan atau modifikasi tindakan yang sama.

Dalam konteks pembelajaran Bahasa Jerman, PTK sering diwujudkan dalam judul yang khas, misalnya: Upaya Peningkatan $X$ dalam Pembelajaran Bahasa Jerman di Y. Redaksi „Upaya Peningkatan“ sejatinya menggambarkan proses tindakan yang dilakukan secara terencana, sistematis, bertahap dan bersiklus pada permasalahan aktual. Upaya peningkatan itu (Bemühungen) sebenarnya merupakan perwujudan integrasi antara teori dan praktik, dimana ide dan metode terbaru dapat diterapkan di lapangan atau di kelas secara proporsional (Dege, 2017). Tindakan dilakukan lebih dari satu kali atau beberapa siklus yang semakin menajam pada penyelesaian masalah, sehingga desainnya menyerupai formasi spiral (a spiral of self-reflective cycles). Sedangkan penyebutan „Y“" merupakan tempat penelitian, dimana hasil temuan hanya berlaku di tempat tersebut dan tidak bisa digeneralisasi pada permasalahan yang sama di tempat berbeda.

Secara ringkas Frank et al. (1998) menyebut, bahwa ciri khas PTK dalam kelas Bahasa
Jerman meliputi konsep pelaksanaan proyek secara spiral dan bertahap. Selain itu, penelitian tersebut berorientasi pada proses pembelajaran. Dalam situasi ini, PTK memungkinkan akses ke pengalaman konkret dan dapat memberikan kontribusi penting untuk fase awal pembentukan teori.

\section{FASE PENELITIAN TINDAKAN KELAS BAHASA JERMAN}

Fase-fase paling esensial dalam PTK adalah proses penemuan fakta (fact finding), perencanaan (planning), tindakan (action) dan evaluasi hasil (evaluation of the results of the action). Pada hakikatnya, tidak ada penelitian tanpa tahapan-tahapan di atas. Bahkan penelitian menjadi tidak bermakna dan tidak dapat menghasilkan kesimpulan signifikan, jika dibangun berdasarkan prosedur yang tidak tertata, terlebih jika bersumber data yang tidak valid.

Secara kompleks, Efron \& Ravid (2013) mendeskripsikan prosedur PTK dalam setiap siklus meliputi: identifikasi permasalahan, pengumpulan informasi latar belakang masalah, desain tindakan, pengumpulan data, interpretasi dan pelaporan hasil.

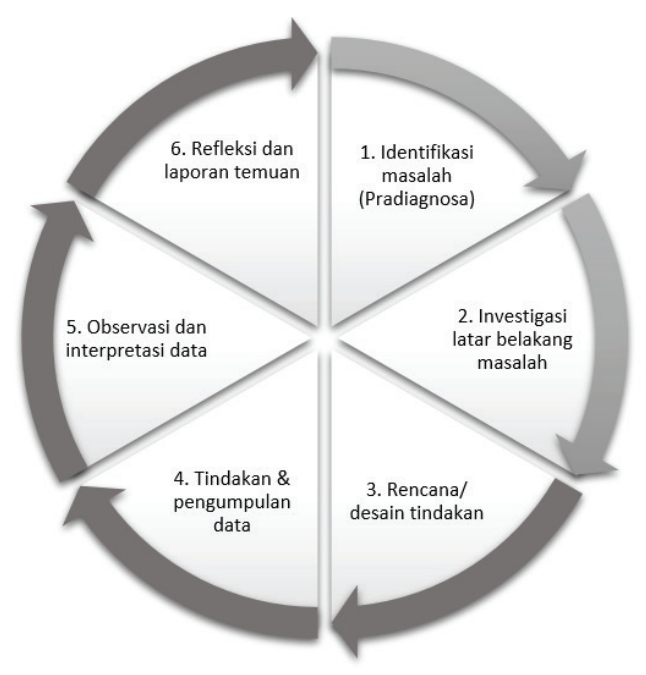

\section{Gambar 1. Prosedur PTK Model Efron \& Ravid}


Model penelitian Efron \& Ravid (2013) merupakan pengembangan dari model-model yang dikenal sebelumnya sejak era 50 -an. Akan tetapi model tersebut di atas memiliki dua fase semu yang menyertai siklus tindakan, yaitu adanya identifikasi masalah dan investigasi latar belakang masalah. Sedangkan fase tindakan dilakukan secara simultan bersama pengumpulan data.

McTaggart et al. (2014) menyebutkan, bahwa pada dasarnya satu siklus cukup terdiri dari perencanaan, aksi, obeservasi dan refleksi. Satu siklus tadi dilanjutkan dengan siklus serupa dan seterusnya.

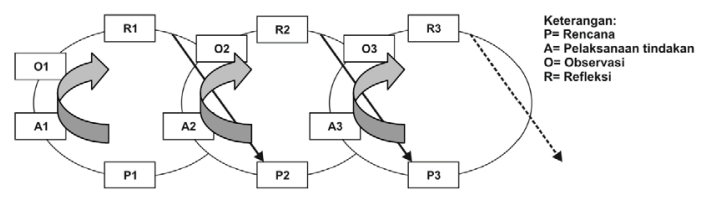

Gambar 2. Prosedur PTK model Mc Taggart

Dari perbandingan kedua prosedur di atas, kita dapat mengetahui, bahwa para pakar berbeda pendapat tentang urutan dan pemakaian istilah pada setiap fase dalam siklus tersebut, sehingga melahirkan banyak model (Prihantoro \& Hidayat, 2019). Fase-fase itu akan diterangkan dalam bab selanjutnya.

Sebagaimana disinggung dalam bab sebelumnya, siklus penelitian tindakan pada kelas Bahasa Jerman dapat dibagi dalam tahapan berikut:

\section{Perencanaan}

Pada tahap pertama, guru mengidentifikasi, membatasi dan merumuskan masalah. Isuisu yang diangkat dalam PTK merupakan hasil pengamatan dan penghayatan guru dalam proses pembelajaran, dimana isu tersebut merupakan persoalan yang urgen, mendesak dan khusus, bukan persoalan yang ditentukan sebelumnya oleh pihak luar. Proses pengamatan atau diagnosa awal dalam penelitian bersifat partisipatif dan sistematis, dimana guru terlibat secara langsung dalam kelas dan memiliki panduan sistematik dalam pengamatan. Daftar komponen diagnosa tersusun secara menyeluruh. Pada fase ini, guru mengamati proses pembelajaran di dalam kelas Bahasa Jerman secara langsung dan mencoba menggali fenomena khusus.

Selanjutnya, guru mempersiapkan seperangkat tindakan. Rencana tindakan perlu memperhatikan kelayakan dan kemampuan guru dalam melaksanakan tindakan. Slameto, (2015) menyatakan, bahwa perencanaan tindakan berdasar pertimbangan beberapa pokok: 1) Kemampuan dan komitmen guru sebagai pelaksana, sebab tindakan PTK harus tumbuh dari keinginan guru sendiri. 2) Kemampuan, kondisi fisik dan situasi siswa dalam mengikuti tindakan tersebut. 3) Ketersediaan sarana yang diperlukan dalam tindakan.

\section{Tindakan}

Elg et al. (2020) menyatakan, bahwa fase tindakan memiliki hubungan erat dengan perencanaan. Dengan kata lain, aksi yang dilakukan pada tahap ini berbasis pada landasan ilmiah dan perencanaan teliti dalam rangka pemecahan masalah. Selanjutnya gagasan-gagasan baru tersebut diuji pada konteks yang spesifik. Selain itu, porsi tindakan perlu dilakukan berdasarkan pertimbangan kewajaran, perubahan situasi, perkembangan peserta didik dan alternatif tindakan penyesuaian terhadap keadaan (Naismith, 2016).

Pada fase ini, ada banyak kegiatan yang harus dilakukan peneliti, terutama adalah implementasi rencana tindakan itu sendiri dan proses pengumpulan data. Pengumpulan data dapat menggunakan banyak instrumen, seperti 
catatan lapangan, lembar observasi, pedoman wawancara, angket dan alat dokumentasi lain untuk mendapatkan data dari guru dan siswa (As Sabiq, 2018).

\section{Observasi}

Fase observasi dilakukan dalam rangka untuk menghayati dan merasakan apa yang dialami oleh kelompok yang diamati. Kegiatan ini dilakukan sampai beberapa kali untuk memastikan, bahwa fenomena yang telah diamati bukan suatu kebetulan, melainkan kondisi riil, baik positif atau pun negatif yang dialami dalam kelas.

Purnomo (2011) membagi teknik observasi menjadi empat jenis, yaitu observasi terbuka, terfokus, terstruktur, dan sistematis.

1) Observasi terbuka ditandai dengan dokumentasi dan catatan bebas tentang segala aktivitas yang berkaitan langsung dengan objek yang diteliti.

2) Observasi terfokus dilaksanakan dengan merekam tujuan yang telah ditentukan sebelumnya.

3) Observasi terstruktur dilaksanakan dengan dibuatnya suatu lembar atau pedoman.

4) Observasi sistematis berisi indikator-indikator yang mungkin muncul. Model pengamatan ini memungkinkan terjadinya identifikasi suatu pola atau kecenderungan khusus pada obyek penelitian.

\section{Refleksi}

Pada tahap akhir setiap siklus tindakan, diadakan refleksi sebagai bahan acuan dalam membuat interpretasi terhadap serangkaian proses beserta hasilnya. Selain itu, refleksi juga diperlukan untuk membuat gagasan baru yang sifatnya merevisi, memperbaiki atau melanjutkan siklus tindakan sebelumnya. Datadata tersebut masih diperjelas dengan catatan lapangan pada setiap aktivitas penelitian berlangsung.

Hidayati (2016) berpendapat, bahwa tahapan ini cukup esensial, dimana peserta didik dan pengajar dapat menilai kelebihan dan kekurangan mereka selama menjalankan tindakan, sehingga kekurangan tersebut dapat mereka atasi pada tindakan selanjutnya. Hal ini selaras dengan pendapat Rothman (2014), bahwa guru dan peserta didik perlu melihat secara kritis tentang seberapa penting upaya yang telah mereka lakukan dalam mencapai tujuan, baik individu maupun kelompok. Mereka perlu merefleksikan nilai kebermaknaan, keberhasilan dan kegagalan dalam siklus tindakan.

Refleksi dapat dibagi menjadi dua bagian, yaitu refleksi proses dan refleksi produk. Pada refleksi proses, guru sebagai peneliti mengevaluasi semua proses tindakan yang sudah dilaksanakan dan berusaha menemukan hal positif-negatif dalam siklus penelitian. Jenis refleksi ini dapat menjelaskan keadaan sesungguhnya, seperti peningkatan adanya motivasi, antusiasme, penghargaan diri, kepercayaan pada kompetensi diri, penggalian ide serta penerapan gagasan. Sedangkan refleksi produk diterapkan berdasarkan penilaian autentik pada hasil kegiatan atau tes. Namun demikian, pencapaian peserta didik tidak hanya semata-mata diukur melalui ranah kognitif atau pengetahuan saja, melainkan juga memperhatikan sikap dan keterampilan peserta didik (Widiyantoro \& Zamzani, 2016).

\section{ASPEK PELAPORAN PENELITIAN TINDAKAN KELAS}

Proses tindakan dalam siklus selalu menghasilkan data dan temuan baru. Oleh sebab itu, penulisan laporan dapat dilakukan pada akhir siklus tindakan sebagai ulasan yang mencakup keseluruhan penelitian. Terlepas dari variasi format dan cakupan laporan yang beragam di 
setiap instansi, penulisan laporan PTK dilakukan secara fleksibel. Friedman et al. (2018) menyatakan, bahwa pelaporan hasil PTK setidaknya mencakup tiga aspek:

1) Adanya nilai tambah (Adding value), artinya laporan itu menunjukkan, bahwa metode PTK dapat membantu peneliti dalam menetapkan kesimpulan temuan dan mengembangkan gagasan baru pada bidang tertentu, meskipun temuan tersebut tidak dapat digeneralisir di semua bidang.

2) Adanya keterangan tentang perubahan yang terjadi (Showing the changes through action research), artinya laporan ini menggambarkan secara detail tentang keadaan dan proses perubahan di kelas, baik pra maupun pasca tindakan;

3) Adanya refleksi kritis terhadap keikutsertaan semua komponen penelitian (Making critical reflection). Hal ini diperlukan oleh guru untuk berbagi pengalaman dalam menjelaskan fenomena yang mengarah pada perkembangan metodologis dan teoretis secara dini.

\section{PENINGKATAN PEMBELAJARAN BAHASA JERMAN MELALUI PENELITIAN TINDAKAN KELAS}

Ngatcha (2004) berpendapat, jika seseorang ingin memperbaiki praktik pengajaran Bahasa Jerman, maka ia harus mampu manginovasi dan meningkatkan kualitas pengajarannya. Dengan kata lain, pelaksanaan proses pembelajaran tersebut harus salalu diperbaiki secara menyeluruh, meliputi evaluasi konsep, efektivitas tindakan dan pencapaian harapan pada hasil yang paling optimal (erreichtete Leistungen im Denken, Handeln, Wollen). Sedangkan jalan untuk mengevaluasi dan meningkatkan proses pembelajaran dapat ditempuh melalui penelitian tindakan kelas. Dengan demikian, peserta didik dapat mencapai stan- dar kualifikasi yang memuaskan dan memenuhi kompetensi kebahasaan yang diperlukan dalam kehidupan sosial dan profesional.

Selain itu, orientasi penyampaian Bahasa Jerman standar harus menjadi inti pembelajaran yang disampaikan dengan penuh nilai dan kebermaknaan (bildungswertig) (Neuland \& Peschel, 2013). PTK dalam pembelajaran Bahasa Jerman dapat dilaksanakan secara optimal dengan pendekatan konstruktivisme, dimana keaktifan guru dan siswa diharapkan muncul secara sinergis dan saling melengkapi. Pendekatan ini mengedepankan fleksibilitas kedekatan sosial dan berbasis akomodasi (Trijanto, 2010).

\section{SIMPULAN}

Pembelajaran Bahasa Jerman merupakan bagian kecil dari bidang pengajaran bahasa asing yang terus berkembang. Tidak mustahil berbagai permasalahan dan tantangan yang mengiringi proses pembelajaran akan terus bermunculan. Oleh karena itu, guru sebagai agen terdepan dalam membelajarkan Bahasa Jerman harus mampu memecahkan persoalan pendidikan lewat metode penelitian yang tepat.

Kehadiran metode PTK dalam penelitian pembelajaran bahasa asing, secara khusus Bahasa Jerman, menjadi pilihan yang sesuai dalam upaya pemecahan masalah. Penerapan PTK dalam pembelajaran Bahasa Jerman diharapkan mampu menyentuh realita persoalan, baik dari sisi sarana pembelajaran, kondisi pembelajar maupun dari sisi guru sebagai pelaksana pendidikan.

\section{UCAPAN TERIMA KASIH}

Ucapan terima kasih kami haturkan kepada Fakultas Bahasa dan Seni, Universitas Negeri Yogyakarta yang telah mendukung penulisan artikel ini. Selain itu, kami juga berterimakasih kepada rekan penulis di Jerman yang telah memberikan masukan dan saran. 


\section{DAFTAR PUSTAKA}

Adamczak-Krysztofowicz, S., \& Stolarczyk, B. (2014). »Virtueller Spaziergang durch meinen und deinen Studienort«Ausgewählte Ergebnisse eines deutsch-polnischen E-Tandemprojekts zwischen der Technischen Universität Darmstadt und derAdam-Mickiewicz-Universität Poznań. Informationen Deutsch Als Fremdsprache, 41(6), 668-684. https:// doi.org/doi:10.1515/infodaf-2014-0608

Apryliana, A. (2017). Keefektifan Pendekatan Proses dan Pendekatan Genre Terhadap Kemampuan Menulis Karangan Argumentasi Siswa SMA. Diksi, 25(1), 1-13. https://doi.org/10.21831/diksi. v25i1.16181

Apryliana, A. (2020). Keefektifan Pendekatan Cooperative Integrated Reading and Composition (CIRC) dalam Pembelajaran Membaca Sastra. Diksi, 28(1), 2432. https://doi.org/10.21831/diksi. v28i1.29869

As Sabiq, A. H. (2018). Improving Students' Motivation and Reading Skills. Diksi, 25(1), 57-68. https://doi.org/10.21831/ diksi.v25i1.16007

Auswärtiges Amt. (2015). Deutsch als Fremdsprache weltweit. In Datenerhebung 2015. https://www.goethe.de/resources/ files/pdf19/1459127-standard.pdf

Auswärtiges Amt. (2020). Deutsch als Fremdsprache weltweit. In Datenerhebung 2020. https://www.auswaertiges-amt.de/ blob/2344738/b2a4e47fdb9e 8 e $2739 \mathrm{bab} 2565 \mathrm{f} 8 \mathrm{fe} 7 \mathrm{c} 2 /$ deutsch-als-fremdsprache-data.pdf

Dahlhaus, B., Funk, H., \& Koenig, M. (1994). Fertigkeit hören. Langenscheidt.

Dahmen, S., \& Hirschfeld, U. (2016). Phonetik in der Unterrichtspraxis. Fremdsprache Deutsch, 55(55), 3. https://doi.or g/10.37307/j.2194-1823.2016.55.03

Dege, M. (2017). Aktionsforschung. In D. Heseler, R. Iltzsche, O. Rojon, J. Rüppel, \& T. D. Uhlig (Eds.), Perspektiven kritischer Psychologie und qualitativer Forschung: Zur Unberechenbarkeit des Subjekts (pp. 317-348). Springer Fachmedien Wiesbaden. https://doi. org/10.1007/978-3-658-14020-5_15

Efron, S. E., \& Ravid, R. (2013). Action Research in Education: A Practical Guide. Guilford Press.

Elg, M., Gremyr, I., Halldórsson, Á., \& Wallo, A. (2020). Service action research: review and guidelines. Journal of Services Marketing, 34(1), 87-99. https://doi. org/10.1108/JSM-11-2018-0350

Frank, U., Klein, S., Krcmar, H., \& Teubner, A. (1999). Aktionsforschung in der WIEinsatzpotentiale und Einsatzprobleme. In Wirtschaftsinformatik und Wissenschaftstheorie (Vol. 4). https://www.pim. wiwi.uni-due.de/uploads/tx_itochairt3/ publications/bericht4.pdf

Friedman, V. J., Gray, P., \& Aragón, A. O. (2018). From doing to writing action research: A plea to ARJ authors. Action Research, 16(1), 3-6. https://doi. org/10.1177/1476750318763041

Harmer, J. (2105). The practice of English language teaching (5th ed.). Pearson.

Haryati, H. (2017). Peningkatan motivasi dan kemampuan menulis teks deskripsi melalui pendekatan proses siswa kelas vii SMP Negeri 5 Magelang. Diksi, 25(2). https://doi.org/https://doi.org/10.21831/ diksi.v25i2.15665

Hidayati, S. (2016). Penggunaan Written Corrective Feedback untuk Meningkatkan Kemampuan Menulis Esai. Diksi, 24(1), 63-72. https://doi.org/10.21831/diksi. v24i1.11500 
Hoch, B., Jentges, S., \& Tammenga-Helmantel, M. (2016). Zielsprachengebrauch in niederländischen DaF-Lehrwerken. Informationen Deutsch Als Fremdsprache, 43(6), 599-622. https://doi.org/0.1515/ infodaf-2016-0605

Hunold, C. (2009). Kulturspezifische Einflüsse der Lehr- und Lernumgebung auf die (Aussprache)leistungen chinesischer Deutschlernender. In K. Peuschel \& J. Pietzuch (Eds.), Kaleidoskop der jungen DaF-/DaZ-Forschung (pp. 49-66). Universitätsverlag Göttingen.

Kast, B. (1999). Fertigkeit Schreiben. Langenscheidt.

McNiff, J., \& Whitehead, J. (2006). All you need to know about action research. Sage Publications.

McTaggart, R., Kemmis, S., \& Nixon, R. (2014). The Action Research Planner Doing Critical Participatory Action Research. Springer. https://doi. org/10.1007/978-981-4560-67-2

Mead, G. (2014). Storytelling. In D. Coglan \& M. Brydon-Miller (Eds.), The SAGE encyclopedia of action research (p. 729). Sage Publications Sage CA: Los Angeles, CA.

Meesuk, P., Sramoon, B., \& Wongrugsa, A. (2020). Classroom action research-based instruction: The sustainable teacher professional development strategy. Journal of Teacher Education for Sustainability, 22(1), 98-110.

Naismith, B. (2016). Integrating corpus tools on intensive CELTA courses. ELT Journal, 71(3), 273-283. https://doi. org/10.1093/elt/ccw076

Neuland, E., \& Peschel, C. (2013). Einführung in die Sprachdidaktik. J. B. Metzler.

Ngatcha, A. (2004). Was kann Aktionsforschung zur Praxis des Fremdsprachenun- terrichts Deutsch beitragen? Informationen Deutsch Als Fremdsprache, 31(4), 422-430. https://doi.org/10.1515/infodaf-2004-0404

Niewalda, K., Schmidt, M. G., \& Sakamoto, S. (2016). Ergänzungsvorschläge für Hörverstehensübungen in deutschen Lehrwerken im universitären DaF-Unterricht in Japan. Informationen Deutsch Als Fremdsprache, 43(6), 623-646. https:// doi.org/10.1515/infodaf-2016-0606

Nolen, A. L., \& Putten, J. Vander. (2007). Action Research in Education: Addressing Gaps in Ethical Principles and Practices. Educational Researcher, 36(7), 401-407.

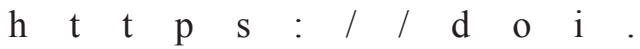
org/10.3102/0013189X07309629

Norton, L. (2009). Action Research in Teaching and Learning: A practical guide to conducting pedagogical research in universities. Routledge.

Pitoyo, A. (2020). Pembelajaran Keterampilan Berbahasa Produktif Berbasis Cooperative Learning: Sebuah Eksperimen Model Pembelajaran Brain dan Investigasi Kelompok. Diksi, 28(2), 171-178. https://doi.org/10.21831/diksi. v28i2.35043

Prihantoro, A., \& Hidayat, F. (2019). Melakukan Penelitian Tindakan Kelas. Ulumuddin : Jurnal Ilmu-Ilmu Keislaman, 9(1), 49-60. https://doi.org/10.47200/ulumuddin.v9i1.283

Purnomo, B. H. (2011). Metode dan Teknik Pengumpulan Data dalam Penelitian Tindakan Kelas (Classroomaction Research). Jurnal Pengembangan Pendidikan, 8(1), 251-256. https://jurnal.unej. ac.id/index.php/JP2/article/view/859

Rösler, D. (2012). Deutsch als Fremdsprache: Eine Einführung. J. B. Metzler. https:// doi.org/10.1007/978-3-476-05284-1 
Rothman, J. (2014). Action Evaluation. In D. Coghlan \& M. Brydon-Miller (Eds.), The $S A G E$ encyclopedia of action research (pp. 5-9). Sage Publications.

Rustam, \& Mundilarto. (2004). Penelitian Tindakan Kelas. Direktorat Pembinaan Pendidikan Tenaga Kependidikan dan Ketenagaan Perguruan Tinggi, Dirjen Pendidikan Tinggi, Depdiknas.

Santoso, I. (2016). Pembelajaran Bahasa Jerman Berbasis Proyek. Jurnal Pendidikan Bahasa Dan Sastra, 12(1). https://doi. org/10.17509/bs_jpbsp.v12i1.3609

Schatz, H., Jenkins, E.-M., Neuf-Münkel, G., \& Roland, R. (2006). Fertigkeit Sprechen. Langenscheidt.

Slameto, S. (2015). Implementasi Penelitian Tindakan Kelas. Scholaria: Jurnal Pendidikan Dan Kebudayaan, 5(3), 47-58. https://doi.org/10.24246/j.scholaria.2015.v5.i3.p47-58

Westhoff, G. (1997). Fertigkeit Lesen. Langenscheidt.

Widayati, A. (2008). Penelitian tindakan kelas. Jurnal Pendidikan Akuntansi Indonesia, 6(1), 87-93.https://doi.org/10.21831/ jpai.v6il.1793

Widiyantoro, A., \& Zamzani. (2016). Penilaian Autentik untuk Meningkatkan Motivasi dan Keterampilan Berbicara Siswa. Diksi, 24(1), 13-26. https://doi. org/10.21831/diksi.v24i1.11495

Wijaya, C., Syahrum, S., \& Ananda, R. (2013). Penelitian tindakan kelas: melejitkan kemampuan penelitian untuk meningkatkan kualitas pembelajaran guru. Citapustaka Media Perintis. 